\title{
A Study on Phosphorus Fixation Capacity in Ultisol Soil Order of North-Eastern India
}

\author{
Bidisha Borpatragohain $^{1 *}$, Dwipendra Thakuria ${ }^{2}$, Samarendra Hazarika ${ }^{3}$, \\ Ashish Rai ${ }^{1}$, Rashmi Priyadarshi ${ }^{1}$ and Subhra Sahoo ${ }^{1}$ \\ ${ }^{1}$ Dr. Rajendra Prasad Central Agricultural University, Pusa, Bihar, India \\ ${ }^{2}$ College of Post Graduate Studies in Agricultural Sciences, \\ Central Agricultural University, Imphal, India \\ ${ }^{3}$ ICAR Research Complex for NEH Region, Umiam, Meghalaya, India \\ *Corresponding author
}

\begin{abstract}
A B S T R A C T
The availability of native phosphorus (P) in Northeast Indian Ultisols, one of the dominant agricultural soils in the region, is relatively low. Given that crop production in North Eastern region is dominated by low external input practices, native $\mathrm{P}$ remains important to plant $\mathrm{P}$ nutrition in many locations. A laboratory experiment was conducted in the College of Post Graduate Studies in Agricultural Sciences, Umiam, Meghalaya. The surface soil samples of 3 soil profiles were used in the study representing the soil order Ultisol. The physical and chemical attributes of the 3 profile soils along with the ability of the profiles to fix phosphorus $(\mathrm{P})$ were determined in this investigation. The order Ultisol comprised of 3 profiles viz., P1, P2 and P3 representing North-West-1 Jorhat (Assam), Mokokchung (Nagaland) and North-West-2Jorhat (Assam), respectively. Results from the incubation experiment (Plevels 0, 25, 50, 100, 200, 300,400, $500,600,700$ and $800 \mathrm{ppm}$ for $24 \mathrm{~h}$ ) indicated that phosphorus fixation capacity (PFC) ( $\mathrm{g} \mathrm{P} \mathrm{g}^{-1}$ soil) ranged from 103 to 577 for the soil profiles of Ultisol. The maximum PFC was obtained at the P application dose $\left(\mu \mathrm{g} \mathrm{g}^{-1}\right.$ soil) for Mokokchung (Nagaland) at 600.The higher percent P fixed was in order of Mokokchung, Nagaland (96.1) > North-West2Jorhat, Assam (84.3)>North-West-1Jorhat, Assam (51.4). The bulk density (BD), maximum water holding capacity (MWHC) and clay content ranged from 0.95 to $1.16 \mathrm{~g} \mathrm{cc}^{-1}, 36.0$ to $54.9 \%$ and 10 to $55 \%$, respectively among the three soil profiles. The content of soil organic carbon (SOC), soil available nitrogen, phosphorus and potassium (Avl.N, Avl.P and Avl.K, respectively) ranged from 1.0 to $2.0 \%, 176$ to $216 \mathrm{~kg} \mathrm{ha}^{-1}, 7.6$ to $62.1 \mathrm{~kg} \mathrm{ha}^{-1}$ and 108 to $205 \mathrm{~kg} \mathrm{ha}^{-1}$, respectively. Soil $\mathrm{pH}$, exchangeable aluminium (Ex.Al), readily soluble aluminium (RS.Al), exchangeable calcium+magnesium (Ex.Ca+Mg) and base saturation (BS) ranged from 4.2 to $4.5,0.46$ to $2.81 \mathrm{meq}^{100 \mathrm{~g}^{-1}}$ soil, 34.6 to $384 \mathrm{mg} \mathrm{kg}^{-1}$ soil, 1.7 to $2.10 \mathrm{meq} 100 \mathrm{~g}^{-1}$ soil, 16.2 to $30.2 \%$, respectively. The soils of Mokokchung (Nagaland) showed the highest percentage of P fixation andNorth-West-1Jorhat (Assam), the least among the three profiles. It is utmost important to enhance the phosphorus use efficiency of these soils, which can be accomplished with the application of phosphatic fertilizers judiciously as the P reserves are depleting rapidly.
\end{abstract}

\begin{tabular}{|l|}
\hline K e y w o r d s \\
Ultisol, Phosphorus \\
fixation capacity, \\
Phosphorus use \\
efficiency, \\
Phosphatic \\
fertilizers \\
\hline Article Info \\
\hline $\begin{array}{l}\text { Accepted: } \\
\text { 18 April } 2020 \\
\text { Available Online: } \\
\text { 10 May } 2020\end{array}$ \\
\hline
\end{tabular}

\section{Introduction}

Ultisols are a group of soil order which occur sporadically in a global band that lies almost completely between latitudes of $40 " \mathrm{~N}$ and40"S. They are prominent in the areas located in the south- eastern United States, northeastern Australia, southwest China, east central Africa, the islands of south-east Asia, and the northeast India. Of the earth's total land mass area, about 5.6 percent (730 million hectares) area is Ultisols (Soil Geography Unit, 1972). Ultisols are often characterized by highly weathered soils having low 
phosphorus (P) stocks and high capacity for $\mathrm{P}$ fixation (Roy et al., 2016). These soils are rich in iron and aluminum oxides that fix $\mathrm{P}$ added in fertilizers before it can be utilized by the crops (Palm et al., 2007; Syers et al., 2008).These soils have low levels of chemical soil fertility, often caused by low levels of available phosphorus (P) (Buresh et al., 1997; Sanchez, 2002). Furthermore, Ultisol soils are able to fix large quantities of fertilizer $\mathrm{P}$, which is considered a main factor lowering the recovery of fertilizer $\mathrm{P}$ by plants. The low $\mathrm{P}$ status of these soils is in sharp contrast to the situation in some areas of the western world where as a result of repeated application of animal manure and $P$ fertilizers, soils have become $\mathrm{P}$ saturated. Despite the often large $\mathrm{P}$ retention capacity of soils, excessive applications of $\mathrm{P}$ may lead to $\mathrm{P}$ leaching to ground- and surface-waters and may contribute to eutrophication of surface waters (Smil, 2000).

The North Eastern region (NER) of India has the largest landmass of acid soils, followed by the neighbouring states of West Bengal, Bihar and Orissa. It is estimated that approximately $91 \%$ soils are acidic, and nearly $65 \%$ soils are suffering from strong acidity $(\mathrm{pH}<5.5)$ in NE India (Sharma et al., 2006).

The causes of low P-use efficiency (PUE) in highly weathered humid sub-tropical soils of $\mathrm{NE}$ India are $\mathrm{Al}$ and $\mathrm{Fe}$ induced $\mathrm{P}$ deficiency (Sharma et al., 2006). The process of $\mathrm{P}$ fixation accelerates the problem leading to low PUE in these soils. Since, there lies spatial variability of $\mathrm{P}$ availability in soils, single blanket recommendation is not appropriate, instead site-specific nutrient management is the need of the hour.

\section{Materials and Methods}

The representative soil profiles of the order Ultisol of NE India considered in this study were from different locations viz. North-
West-1Jorhat, Assam (P1); Mokokchung, Nagaland; (P2) and North-West-2Jorhat, Assam (P3). The soil samples from surface layers (0-15 cm depth) were collected for laboratory analysis and some basic physicochemical properties (Soil texture, soil colour, pH, SOC, Available. N, P, K, Exchangeable $\mathrm{Ca}$ and $\mathrm{Mg}$, Readily soluble $\mathrm{Al}$, CEC, Exchangeable aluminum, Base saturation) of the soils were determined (Fig. 1).

An amount of $5 \mathrm{~g}$ soil was taken in each conical flask (capacity $100 \mathrm{ml}$ ). The graded levels of $\mathrm{P}(0,25,50,100,200,300,400,500$, 600,700 and $800 \mathrm{mg} \mathrm{P}_{2} \mathrm{O}_{5} \mathrm{~kg}^{-1}$ soil) were imposed to each profile soil maintaining 3 replicate flasks. Immediately after addition of $\mathrm{P}$ levels, $25 \mathrm{ml}$ of $0.01 \mathrm{M} \mathrm{CaCl}_{2}$ solution was added to each conical flask and these flasks were incubated for $24 \mathrm{~h}$ in a gyratory shaker at rpm 120.

After incubation, soil suspension was filtered through Whatman filter paper no. 42 and then the concentration of $\mathrm{P}$ in the clears upernatant was determined using stannous chloride blue colour method. The percent $\mathrm{P}$ fixed was calculated by dividing fixed $\mathrm{P}$ amount with added $\mathrm{P}$ amount and multiplying it with 100 . The formula used to calculate percent $\mathrm{P}$ fixed is given below:

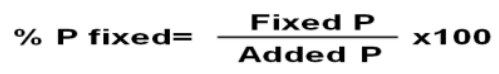

Quantity of fixed P = (Quantity of P applied Quantity of $\mathrm{P}$ in solution - Quantity of solution $\mathrm{P}$ in blank)

\section{Statistical analysis}

Univariate statistics were performed using SPSS v12.0 (Statistical Packages for Social Science Inc., Chicago, IL, USA). Means were tested at a significant level of $\mathrm{P} \leq 0.05$ using Tukey's HSD test for multiple pair-wise comparisons among means. 


\section{Results and Discussion}

\section{Physico-chemical properties of the profiles}

The colour of the soils in dry conditions ranged from light olive brown to yellowish brown viz., $2.5 \mathrm{Y} 5 / 4$ to $10 \mathrm{YR} 5 / 4$ and under moist conditions ranged from olive brown to dark brown viz., $2.5 \mathrm{Y} 4 / 4$ to $10 \mathrm{YR} 3 / 3$. The sand content varied from 35 to $85 \%$ and clay content ranged from 10 to $55 \%$. The maximum clay content was $55 \%$ in $\mathrm{P} 2$ and minimum was $10 \%$ in P3. The values of silt content varied from 5-10\%. The rapid fixation of $\mathrm{P}$ by clay minerals is attributed to its reaction with readily available $\mathrm{Fe}$ and $\mathrm{AI}$ in soils (Tening et al., 2013; Goundar et al., 2014). The texture varied from loamy sand to clay. The values of BD ranged from 0.95 to $1.16 \mathrm{~g} \mathrm{cc}^{-1}$ among the 3 profiles and the highest was found in P3. The water holding capacity ranged from $36.0 \%$ in $\mathrm{P} 3$ to a maximum of $54.9 \%$ in $\mathrm{P} 2$. Among all the 3 profiles, P3 had the least capacity to hold water.

Soil $\mathrm{pH}$ values ranged from 4.22 to 4.56 that are from extremely acidic to very strongly acidic. The $\mathrm{pH}$ of P3profile soil was the highest and P1 soil was the lowest among Ultisols. Most soils of the tropics (predominantly Ultisols) are acidic in nature due to high rainfall and high weathering that lead to basic cations removal from the soil. In such soils, acidic cations such as $\mathrm{Al}$ and $\mathrm{Fe}$ predominate, and depending on soil $\mathrm{pH}$, they fix the applied inorganic P (Adnan et al., 2003). The PFC of soils increased with decrease in soil $\mathrm{pH}$, which was evident from the significant negative correlation $(\mathrm{r}=$ $0.58^{* *}$ ) between soil $\mathrm{pH}$ and PFC in this study. The similar relationship between PFC and soil $\mathrm{pH}$ was previously noticed (Kanwar and Grewal, 1990; Naidu et al., 1990). Soil organic carbon varied from $1.0 \%-2.0 \%$. The content of SOC was the highest $(2.0 \%)$ for P2 and the least $(1.0 \%)$ was for P3. The highest percent SOC may be due to the clayey nature of soil from P2. The content of soil Avl.N ranged from $176 \mathrm{~kg} \mathrm{ha}^{-1}$ to $216 \mathrm{~kg} \mathrm{ha}^{-1}$ and P2 contained maximum Avl.N and minimum was for P3 soil. The content of Avl.P varied from $7.6 \mathrm{~kg} \mathrm{ha}^{-1}$ to $62.1 \mathrm{~kg} \mathrm{ha}^{-1}$. The highest $\mathrm{P}$ was found in P1 soils and the lowest in P3 soils. The P2 soil contained maximum Avl.K (205 $\left.\mathrm{kg} \mathrm{ha} \mathrm{ha}^{-1}\right)$ and the minimum content (108 $\mathrm{kg} \mathrm{ha}^{-1}$ ) for P3 soils. The P3 had the least amount of Avl.K among all the profiles. Exchangeable alumina (Ex. Al) ranged from 0.46 meq $100^{-1} \mathrm{~g}$ to $2.81 \mathrm{meq} 100^{-1} \mathrm{~g}$. The P3 soil had the highest amount and P1 had the least amount of Ex.Al. The higher content of readily soluble alumina was due to low soil $\mathrm{pH}$ of the soil. The P2 soils contained the highest amount of readily soluble alumina (384 $\mathrm{mg} \mathrm{kg}^{-1}$ ) and the lowest (34.6 $\mathrm{mg} \mathrm{kg}^{-1}$ ) was $\mathrm{P} 4$ soil. In addition to very low soil $\mathrm{pH}$, the high amount of Ex.Al (41.4 to 253 mg kg${ }^{-1}$ soil) and RS.Al (34.6 to $384 \mathrm{mg} \mathrm{kg}^{-1}$ soil) might be the responsible factor for higher PFC values. The content of DTPA-Fe varied from $20.3 \mathrm{mg} \mathrm{kg}^{-1}$ to $24.5 \mathrm{mg} \mathrm{kg}^{-1}$. The content of Exch.Ca+Mg ranged from $1.7 \mathrm{meq}$ $100^{-1} \mathrm{~g}$ soil to $2.1 \mathrm{meq} 100^{-1} \mathrm{~g}$ soil. The values of CEC ranged from 6.6 to $14.2 \mathrm{cmol} \mathrm{kg}^{-1}$ and the percent BS ranged from $16.2 \%$ to $30.2 \%$ for the 3 soil profiles belonging to Ultisol. Higher values of BS was in P3 due to high CEC and high amount of Ex.Ca+Mg and low BS values was in P2due to low amount of Ex.Ca+Mg (Table 1).

\section{Soil profiles and their phosphate fixation capacity}

The values of maximum quantity of applied $\mathrm{P}$ fixed and \% P fixed ranged from 102.8 to $576.7 \mu \mathrm{g} \mathrm{P} \mathrm{g}^{-1}$ soil and 51.4 to $96.1 \%$, respectively for Ultisol profiles P1, P2 and P3 (Fig. 2). The $\mathrm{P}$ dose at which maximum PFC value obtained for $\mathrm{P} 1, \mathrm{P} 2$ and $\mathrm{P} 3$ profiles were 200,600 and $400 \mu \mathrm{g} \mathrm{P} \mathrm{g}^{-1}$ soil, respectively (Fig. 2). 
Table.1 Physico-chemical properties of surface soils of the three profiles of Ultisol

\begin{tabular}{|c|c|c|c|}
\hline Profile & \multirow{2}{*}{$\begin{array}{c}\text { P1 } \\
2.5 \text { YR } 6 / 4\end{array}$} & \multirow{2}{*}{$\begin{array}{c}\text { P2 } \\
10 \text { YR 5/4 }\end{array}$} & \multirow{2}{*}{$\begin{array}{c}\text { P3 } \\
2.5 \text { Y } 5 / 4\end{array}$} \\
\hline Soil colour & & & \\
\hline Moist & $2.5 \mathrm{Y} 4 / 4$ & 7.5 YR 3/4 & $10 \mathrm{YR} 3 / 3$ \\
\hline Coarse sand $(\%)$ & 14.7 & 3.85 & 11.85 \\
\hline Fine sand (\%) & 65.3 & 31.15 & 73.15 \\
\hline Silt (\%) & 5 & 10 & 5 \\
\hline Clay (\%) & 15 & 55 & 10 \\
\hline Textural Class & sandy loam & clay & loamy sand \\
\hline BD $\left(\mathrm{g} \mathrm{cc}^{-1}\right)$ & $1.14 \pm 0.005 \mathrm{e}$ & $0.95 \pm 0.005 b$ & $1.16 \pm 0.011 \mathrm{ef}$ \\
\hline MWHC (\%) & $36.3 \pm 0.88 \mathrm{abc}$ & $54.9 \pm 0.404 \mathrm{e}$ & $36.0 \pm 0.69 \mathrm{abc}$ \\
\hline FC $(\%)$ & $26.3 \pm 0.12 b c$ & $41.2 \pm 0.29 \mathrm{~g}$ & $27.0 \pm 0.52 \mathrm{c}$ \\
\hline pH & $4.22 \pm 0.058 \mathrm{a}$ & $4.33 \pm 0.036 \mathrm{a}$ & $4.56 \pm 0.066 b c$ \\
\hline $\operatorname{SOC}(\%)$ & $1.20 \pm 0.057 \mathrm{bc}$ & $2.00 \pm 0.288 \mathrm{e}$ & $1.00 \pm 0.057 \mathrm{ab}$ \\
\hline Avl.N (kg ha $\left.{ }^{-1}\right)$ & $210 \pm 4.9 \mathrm{~cd}$ & $216.30 \pm 4.0 \mathrm{~d}$ & $176 \pm 5.7 b$ \\
\hline Avl.P (kg ha $\left.{ }^{-1}\right)$ & $62.1 \pm 0.55 \mathrm{~g}$ & $9.20 \pm 0.529 b c$ & $7.60 \pm 0.321 \mathrm{ab}$ \\
\hline $\operatorname{Avl.K}\left(\mathrm{kg} \mathrm{ha}^{-1}\right)$ & $195 \pm 2.06 \mathrm{c}$ & $205 \pm 4.0 \mathrm{~cd}$ & $108 \pm 1.334 \mathrm{~cd}$ \\
\hline DTPA-Fe (mg kg-1 soil) & $21.20 \pm 1.86 \mathrm{a}$ & $24.46 \pm 2.08 \mathrm{ab}$ & $20.26 \pm 0.58 \mathrm{a}$ \\
\hline $\begin{array}{c}\text { Ex.Al } \\
\left(\text { meq } 100^{-1} \text { soil }\right)\end{array}$ & $0.46 \pm 0.022 \mathrm{~d}$ & $1.06 \pm 0.030 \mathrm{e}$ & $2.81 \pm 0.100 f$ \\
\hline $\begin{array}{c}\text { RS.Al } \\
\left(\mathrm{mg} \mathrm{kg}^{-1} \text { soil }\right)\end{array}$ & $34.6 \pm 1.73 a$ & $384 \pm 5.8 \mathrm{e}$ & $318 \pm 5.7 \mathrm{c}$ \\
\hline $\begin{array}{c}\text { Ex.Ca+Mg } \\
{\left[\mathrm{cmol}\left(\mathbf{P}^{+}\right) \mathbf{k g}^{-1} \text { soil }\right]}\end{array}$ & $2.10 \pm 0.231 \mathrm{a}$ & $1.80 \pm 0.115 \mathrm{a}$ & $1.70 \pm 0.0578 \mathrm{a}$ \\
\hline $\begin{array}{c}\text { CEC } \\
{\left[\mathrm{cmol}\left(\mathbf{P}^{+}\right) \mathrm{kg}^{-1} \text { soil }\right]}\end{array}$ & $8.90 \pm 0.923 \mathrm{ab}$ & $14.2 \pm 1.27 \mathrm{~cd}$ & $6.60 \pm 0.058 \mathrm{a}$ \\
\hline BS $(\%)$ & $28.9 \pm 1.70 b c$ & $16.2 \pm 1.13 \mathrm{a}$ & $30.2 \pm 2.86 b c$ \\
\hline
\end{tabular}

Values \pm means, $\mathrm{n}=3$; Within a column (parameter) values followed by different letters are statistically significant as determined by one-way ANOVA incorporating Tukey's HSD test for multiple pair-wise comparisons among means. BD - bulk density, MWHC - maximum water holding capacity, FC - field capacity, SOC - soil organic carbon, Avl.N - soil available N, Avl.P - soil available P, Avl.K - soil available K, DTPA-Fe - soil available Fe, Ex.Al exchangeable aluminium, RSA - readily soluble aluminium, Ex.Ca+Mg - exchangeable ca+Mg, CEC - cation exchange capacity and BS - base saturation. 
Table.2 The maximum quantity of applied $\mathrm{P}$ fixed at the $\mathrm{P}$ dose where the highest $\% \mathrm{P}$ fixed in soils of the three profiles

\begin{tabular}{|c|c|c|c|c|}
\hline Profile & Soil order & $\begin{array}{l}\text { Maximum quantity } \\
\text { of applied P fixed } \\
\left(\mu \mathrm{g} \mathrm{Pg}^{-1} \text { soil }\right)\end{array}$ & $\begin{array}{c}\text { P fixed } \\
(\%)\end{array}$ & $\begin{array}{l}\text { P dose at which max. } \\
\text { PFC point achieved } \\
\left(\mu \mathrm{g} \mathrm{Pg}^{-1} \text { soil }\right)\end{array}$ \\
\hline $\mathrm{P} 1$ & \multirow{3}{*}{ Ultisol } & $102.8 \pm 3.1 \mathrm{~b}$ & 51.4 & 200 \\
\hline $\mathrm{P} 2$ & & $576.7 \pm 4.6 \mathrm{i}$ & 96.1 & 600 \\
\hline P3 & & $337.0 \pm 4.0 f$ & 84.3 & 400 \\
\hline
\end{tabular}

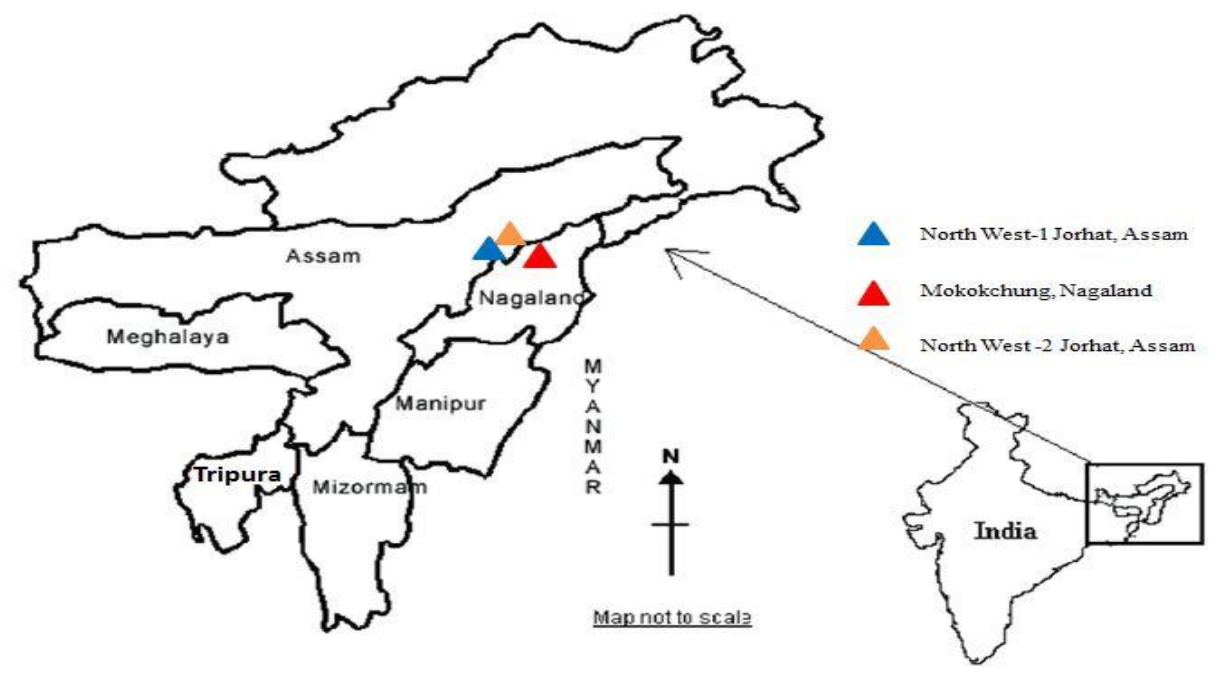

Fig.1 Sampling locations of the study area
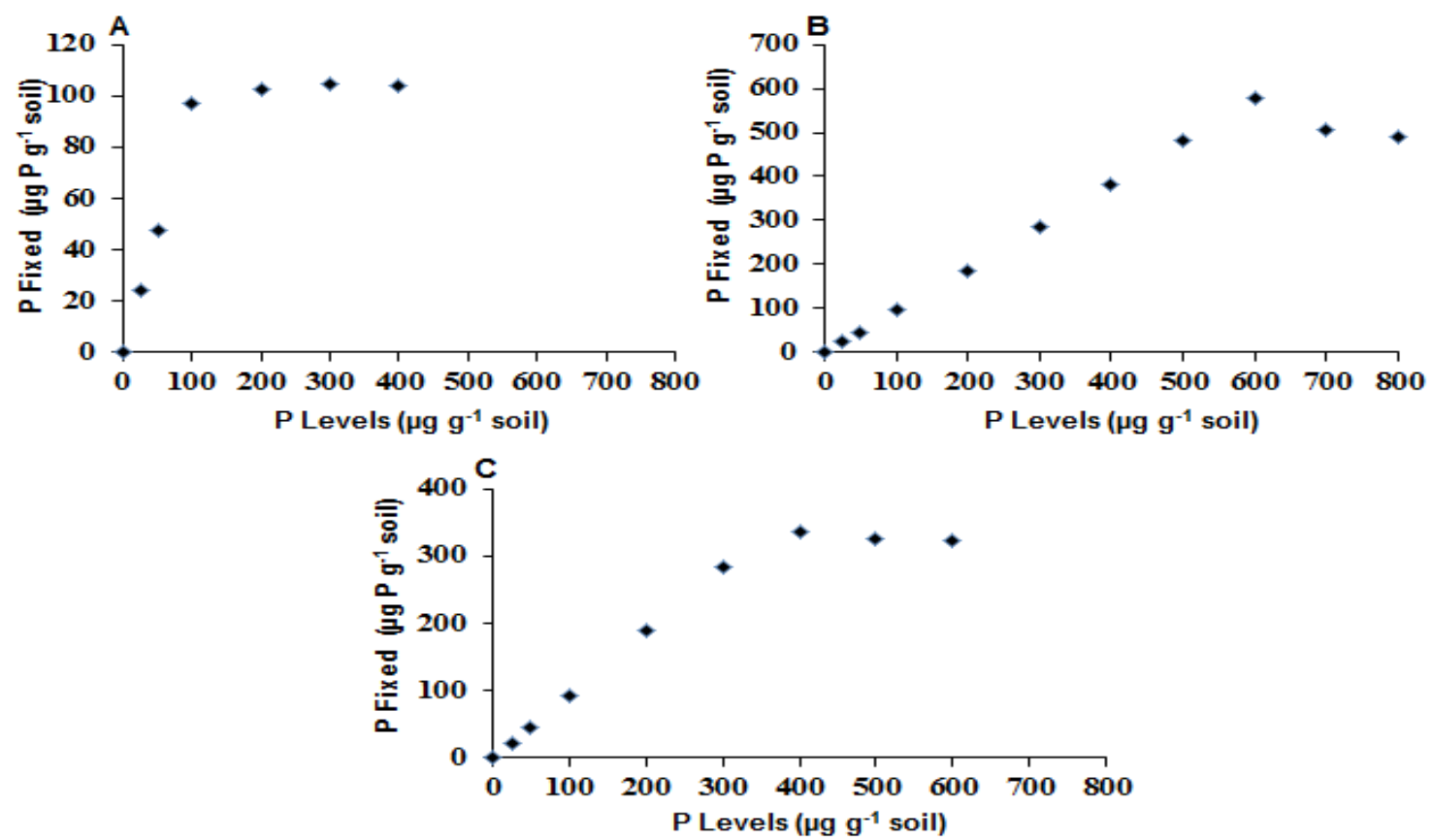

Fig.2 Phosphate fixation capacity curves of Ultisols representing 3 soil profiles

(A) Profile 1, (B) Profile 2 and (C) Profile 3 
Ultisols are expected to show a high affinity for $\mathrm{P}$ since they are dominated by oxyhydroxides and kaolinite in soil. Our findings indicated that Ultisol order had the highest PFC which ranged from 103 to 577 $\mu \mathrm{g} \mathrm{P} \mathrm{g}^{-1}$ soil and \% $\mathrm{P}$ fixed ranged from 85.1 to 96.1. In past, Syers et al., (1971) reported such higher PFC of highly weathered soils such as Oxisols and Ultisols. The relatively lesser quantity of applied P fixed (103 $\mu \mathrm{g} \mathrm{P} \mathrm{g}$ ${ }^{1}$ soil) and lesser \% P fixed (51.4) by P1 soil in comparison to that in soils of P2 and P3 was an exception. The possible reason was that the Profile 1 falls within a commercial Tea garden (located in North West-1, Jorhat) where inorganic fertilizers were applied regularly since last 50 years that lead to accumulation of $\mathrm{P}$ in soil which might partially saturated the $P$ fixation sites and as a result higher content of soil Avl.P content (Table 2).

Because of build-up of inorganic $\mathrm{P}$ pools which could satisfy the $\mathrm{P}$ adsorption sites of clay minerals and $\mathrm{Al}$ and $\mathrm{Fe}$ oxides and hydroxides in P1 soils, the PFC was found lower (only $102 \mu \mathrm{g} \mathrm{g}^{-1}$ soil) as compared to the range (337 to $576 \mu \mathrm{g} \mathrm{g}^{-1}$ so) for P2 and P3 soils. This justification could be further supported by higher soil Avl.P content (62.1 $\mathrm{kg} \mathrm{ha}^{-1}$ ) for P1 soil as against the range of soil Avl.P content (7.6 to $9.2 \mathrm{~kg} \mathrm{ha}^{-1}$ ) for P2 and $\mathrm{P} 3$ soil. The accumulation of $\mathrm{P}$ due to continuous application of inorganic $P$ fertilizers in peach orchard under humid subtropics of Eastern Himalayas was recently report by Surchand-Singh et al., (2017). So, it can be mentioned that the right dose of $\mathrm{P}$ with suitable management practices (liming with organic manures) may offset the $\mathrm{P}$ deficiency or toxicity problem in acid soils of tropics and subtropics (Franklin, 2012).

Out of three soil profiles, Mokokchung (Nagaland) possess very high PFC and NorthWest-1Jorhat (Assam), possesses relatively the lowest PFC.
The higher percent $\mathrm{P}$ fixed was in the order of Mokokchung, Nagaland (96.1) > North-West2Jorhat, Assam (84.3)>North-West-1Jorhat, Assam (51.4). For agricultural practice, the low-input strategy is recommended. Frequent applications at modest rates are more effective than less frequent applications at higher rates.

So, the PFC findings of this study calls for an urgent need to correct the existing blanket recommended dose of phosphatic fertilizer. There is a need for formulation of suitable nutrient management practice that can improve the status of these soil attributes so as to reduce the PFC and enhancing the PUE of soil. Findings of this investigation revealed the fundamental understanding on PFC of Ultisol of NE India and based on which efficient $\mathrm{P}$ management practice needs to be formulated and tested for effectiveness against the existing blanket recommendation of phosphatic fertilizer.

\section{Acknowledgements}

The laboratory facility provided by the School of Natural Resource Management, College of Post Graduate studies in Agricultural Sciences, Umiam under Central Agricultural University, Imphal for carrying out soil analysis for the present study is duly acknowledged.

\section{References}

Adnan, A., Mavinic, D.S., and Koch, F.A., 2003. Pilot-scale study of phosphorus recovery through struvite crystallization-examining to process feasibility. J. Environ. Eng. Sci., 2: $315-24$.

Buresh, R.J., Smithson, P.C., Hellums, D.T., 1997. Building soil phosphorus capital in Africa. In: Buresh, R.J., Sanchez, P.A. (Eds.), Replenishing Soil Fertility in Africa. SSSA Special 
Publication, Madison, WI, USA, pp. 111-149.

Franklin, O.N., 2012. Ameliorating soil acidity in Ghana: A concise review of approaches. J. Sci. Technol., 2: 1-9.

Goundar, M.S., Morrison, R.J., and Togamana, C., 2014. Phosphorus requirements of some selected soil types in the Fiji sugarcanebelt. South Pacific J. Nat. Applied Sci., 32 (1): 110.

Kanwar, J.S., and Grewal, J., 1990. Phosphorus fixation in Indian soils. Second edition. Indian Council of Agricultural Research, New Delhi, India.

Naidu, R., Syers, J.K., Tillman, R.W., and Kirkman, J.H., 1990. Effect of liming on phosphate soption by acid soils. Soil Sci., 41: 163 -175.

Palm, C., Sanchez, P., Ahamed, S., Awiti, A., 2007. Soils: a contemporary perspective. Annu. Rev. Environ. Resour. 32, 99-129.

Roy, E.D., Richards, P.D., Martinelli, L.A., Della Coletta, L., Machado Lins, S.R., Ferraz Vazquez, F., Willig, E., Spera, S., Van Wey, L.K., Porder, S., 2016. The phosphorus cost of agricultural intensification in the tropics. Nat. Plants 2, 16043.

Sanchez, P.A., 2002. Soil fertility and hunger in Africa. Science. 295, 20192020.

Sharma, P.D., Baruah, T.C., Maji, A.K., and Patiram, 2006. Management of acid soils of NEH Region. Indian Council of Agricultural Research, KrishiAnusandhanBhavan, Pusa Campus, New Delhi, pp. 45-60.

Smil, V., 2000. Phosphorus in the environment: natural flows and human interferences. Ann. Rev. Energy Environ. 25, 53-88.

Soil Geography Unit, 1972. Soils ofthe World. Map. USDA Soil Conservation Service, Washington, D.C.

Surchand-Singh K., Hazarika S., Thakuria D., Bordoloi L.J., and Deka B.C., 2017. Long-term management impact on soil quality under Peach (Prunis persica L.) orchard in humid subtropics of Eastern Himalayas. J. Indian Soc. Soil Sci., 65(4): 401-409.

Syers, J.K., Evans, T.D., Williams, D.H., and Murdock, J.T., 1971. Phosphate sorption parameters of representative soils from Rio Grande do sul, Brazil. Soil Sci., 112: 267-275.

Syers, J.K., Johnston, A.E., Curtin, D., 2008. Efficiency of soil and fertilizer phosphorus use: Reconciling changing concepts of soil phosphorus behavior with agronomic information. FAO Fertilizer and Plant Nutrition Bulletin. Food and Agriculture Organization of the United Nations, pp. 18.

Tening, A.S., Foba-Tendo, J.N., YakumNtaw, S.Y., and Tchuenteu, F., 2013. Phosphorus fixing capacity of a volcanic soil on the slope of mount Cameroon. Agric. Biol. J. N. Am., 4(3): 166-174.

\section{How to cite this article:}

Bidisha Borpatragohain, Dwipendra Thakuria, Samarendra Hazarika, Ashish Rai, Rashmi Priyadarshi and Subhra Sahoo. 2020. A Study on Phosphorus Fixation Capacity in Ultisol Soil Order of North-Eastern India. Int.J.Curr.Microbiol.App.Sci. 9(05): 2354-2360. doi: https://doi.org/10.20546/ijcmas.2020.905.268 